\title{
Perbandingan Efek Antibakteri Madu Asli Sikabu dengan Madu Lubuk Minturun terhadap Escherichia Coli dan Staphylococcus Aureus secara In Vitro
}

\author{
Yugo Berri Putra Rio, Aziz Djamal, Asterina.
}

\section{Abstrak}

Pendahuluan: Madu digunakan sebagai agen makanan dan obat tradisional, mengandung nektar atau gula eksudat dari tanaman yang dikumpulkan oleh lebah madu serta merupakan salah satu obat tradisional yang digunakan oleh masyarakat. Madu diketahui memiliki kemampuan sebagai efek antibakteri, seperti Escherichia coli dan Stahpylococcus aureus. Kedua bakteri ini memiliki sifat yang berbeda tetapi memilki kesamaan dari penyakit yang disebabkannya. Kualitas dan jenis madu juga sesuai dengan tempat dan lokasi lebah berkembang biak. Tujuan penelitian ini adalah untuk melihat perbandingan efek antibakteri madu asli Sikabu dan Lubuk Minturun terhadap Escherichia coli dan Staphylococcus aureus secara in vitro. Metode Penelitian: Madu yang diuji untuk penelitian ini adalah madu yang berasal dari Sikabu dan Lubuk Minturun. Penelitian ini dilaksanakan pada bulan Desember 2011 sampai Mei 2012 di laboratorium Mikrobiologi Fakultas Kedokteran Universitas Andalas. Jenis penelitian yang digunakan adalah eksperimental dengan menggunakan metode difusi (metode cakram) dan analitik dengan menghubungkan perbedaan yang dimiliki kedua madu sebagai efek antibakteri. Hasil Penelitian: ini menunjukkan bahwa madu asli Sikabu dan Lubuk Minturun tidak memiliki kemampuan efek antibakteri terhadap Escherichia coli, dan terdapat perbedaan efek antibakteri dari kedua madu terhadap Staphylococcus aureus.

Kesimpulan: dari kedua jenis madu yang diteliti tidak ditemukan efek antibakteri terhadap Escherichia coli , namun madu asli Sikabu memiliki efek antibakteri yang lebih baik dari pada madu Lubuk Minturun terhadap Staphylococcus aureus

Kata Kunci : Perbandingan Efek Antibakteri, Madu Asli Sikabu, Madu Lubuk Minturun. Escherichia coli, Staphylococcus aureus

\section{Abstract}

Introduction: Honeyis used as an agent for food and traditional medicine, containing nectar or sugar exudates of the plant collected by honey bees, is one of the traditional medicines used by community. Honey is known to have the ability as an antibacterial effect, such as Escherichia coli and Stahpylococcus aureus. Both of these bacteria have different properties but have the common of the diseases it causes. The quality and type of honey is also in accordance with the breeding places and their location. The purpose of this study was to see a comparison of the antibacterial effect of honey Sikabu and Lubuk Minturun against Escherichia coli and Staphylococcus aureus by in vitro. Methods: Honey to be tested for this study were derived from Sikabu and Lubuk Minturun. This study was conducted in December 2011 to May 2012 in the laboratory of Microbiology, Faculty of Medicine, Andalas University. Type of research is experimental diffusion method (disc method) and analytical distinction owned by linking the two of honey as an antibacterial effect. Results: These results indicate that the honey Sikabu and Lubuk Minturun have no antibacterial effect against Escherichia coli, both of honey have differences antibacterial effect against Staphylococcus aureus. Conclusion: Both types of honey from this study did not find an antibacterial effect against Escherichia coli, but honey Sikabu has better antibacterial against Staphylococcus aureus than honey Lubuk Minturun.

Keywords: Comparisons Antibacterial Effects, Original Sikabu Honey, Honey Lubuk Minturun. Escherichia coli, Staphylococcus aureus

Affiliasi penulis : Fakultas Kedokteran, Universitas Andalas, Jalan Perintis Kemerdekaan No. 94, Padang

Korespondensi : Yugo Berri Putra Rio, Fakultas Kedokteran, Universitas Andalas, Jalan Perintis Kemerdekaan No. 94, Padang

\section{Pendahuluan}

Sejarah madu menjadi komersial selama abad 19, terutama hal-hal yang telah dilakukan oleh para penelitisebelumnya.Kelebihan madu di dunia kedokteran pertama kali diperkenalkan oleh
Hippocrates (460 SM - 370 SM). Beliau tercatat sebagai orang yang menggunakan madu sebagai ekspetoran dan menyatakan bahwa hal ini bisa menyebabkan panas, yang berguna untuk membersihkan bisul, dan luka. ${ }^{(7)}$

Madu digunakan sebagai makanan dan agen obat. Madu mengandung suatu zat yang dapat mengurangi efek penuaan, memulihkan vitalitas, dan menurunkan kolesterol.Selain tinggi vitamin, mineral, dan antioksidan properti, juga terdapat beberapa zat dalam madu yang memiliki sifat antibiotik yang kuat 
sertamembantu dalam penyembuhan jaringan mati, luka, dan bisul. Madu alam mempunyai konsentrasi gula yang tinggi, dimana bakteri tidak dapat bertahan hidup dalam madu. ${ }^{(3,9)}$

Secara ilmiah telah terbukti bahwa bakteri tidak dapat hidup dan berkembang di dalam madu karena ia mengandung unsur potassium (kalium), yaitu unsur yang mencegah kelembaban, yang merupakan unsur terpenting untuk pertumbuhan bakteri (efek inhibisi). Madu memiliki zat antibiotik seperti interferon yang anti-virus, dan inhibin yang dapat menghambat pertumbuhan bakteri. Eksperimen yang dilakukan pada madu, didapatkan bahwa cairan madu lebah segar memiliki 50\% untuk membasmi bakteri penyebab meningitis dan $25 \%$ untuk membasmi bakteri organik secara jelas, di mana meningitis merupakan salah satu penyakit yang disebabkan oleh bakteri, seperti Staphylococcus aureus dan Escherichia coli. Infeksi Staphylococcus aureus dan Escherichia coli yang sudah menyebar melalui aliran darah sehingga terjadi bakteremia dapat menimbulkan mengitis, dan infeksi Escherichia coli juga menjadi penyebab meningitis sekitar $40 \%$ pada kasus meningitis neonatal. ${ }^{(1,9)}$

Staphylococcus aureus merupakan salah satu genus dari Staphylococcus yang bersifat patogen utama bagi manusia. Staphylococcus aureus yang patogen dan invasif cenderung menghasilkan koagulase, pigmen kuning, dan bersifat hemolitik. Infeksi bakteri ini dapat disebabkan oleh kontaminasi langsung pada luka, misalnya pada infeksi luka pascabedah oleh Staphylococcus atau infeksi setelah trauma. Escherichia coli adalah salah satu dari bakteri enterik dan anggota flora usus normal. Bakteri ini bersifat patogen apabila berada di luar usus, yaitu lokasi normal tempatnya berada atau di lokasi lain di mana flora normal jarang terdapat. Tempat yang paling sering terkena infeksi yang paling penting secara klinik adalah saluran kemih, saluran empedu, dan tempat-tempat lain di rongga perut, kemudian ketika ketahanan tubuh inang tidak adekuat dapat menimbulkan infeksi lokal yang secara klinik dapat mencapai aliran darah lalu menimbulkan sepsis. $^{(1,2,5,8,11)}$

Madu telah terbukti memiliki penyembuhan luka dan sifat antimikroba, tapi ini tergantung pada jenisnya, lokasi geografis, dan bunga dari mana produk akhir berasal. Ilmuwan telah menguji aktivitas antimikroba dari madu Chili yang dibuat oleh Apis mellifera (lebah madu) yang berasal dari pohon Ulmo (Eucryphia cordifolia) dan madu Manuka yang berasal dari pohon Manuka (Leptospermum scoparium) yang saat ini dijual sebagai agen terapeutik seluruh dunia. Penelitian para ilmuwan tersebut dilakukan secara in vitro terhadap strain bakteri yang dipilih, yaitu Staphylococcus aureus, Escherichia Coli, dan Pseudomonas aeruginosa. Penelitian tersebut menghasilkan suatu perbedaan dari sifat kedua madu sebagai antibakteri, yakni menunjukkan bahwa madu Ulmo memiliki efek antibakteri yang unggul dibandingkan madu Manuka. Hasil penelitian berdasarkan aktivitas antibakteri berdasarkan pada zona kliring yang dihasilkan. Madu Ulmo menghasilkan efek antibakteri yang besar atau setara dengan madu Manuka untuk pengenceran setiap saat diuji terhadap lima isolat dari ketiga bakteri tersebut. Penelitian yang dilakukan pada konsentrasi yang lebih rendah, Madu Ulmo selalu menghasilkan efek antibakteri yang lebih baik daripada madu Manuka. ${ }^{(6,}$

Di Sumatera Barat terdapat beberapa daerah penghasil madu, di antaranya adalah madu dari Sikabu dan Lubuk Minturun. Kedua madu ini berasal dari lokasi yang berbeda, di mana madu Sikabu berasal dari kecamatan di Padang Pariaman, sedangkan madu Lubuk Minturun merupakan madu yang berasal dari salah satu kelurahan di Kecamatan Koto Tangah, kota Padang. Kedua madu dari wilayah tersebut merupakan madu yang terkenal di Sumatera Barat, penelitian dari efek antibakteri yang dimiliki oleh kedua madu tersebut belum pernah dilakukan sampai saat ini.

Penelitian ini dilakukan dengan tujuan untuk mengetahui perbandingan efek antibakteri madu Lubuk Minturun dan madu Sikabu terhadap Escherichia coli dan Staphylococcus aureus secara in vitro.

\section{Metode}

Penelitian ini dilakukan di laboratorium Mikrobiologi Fakultas Kedokteran Universitas Andalas Padang pada bulan Desember 2011 sampai Mei 2012. Sampel adalah madu lebah yang diambil dari dua daerah yang berbeda yang didapat dari Sikabu dan Lubuk Minturun dengan menggunakan metode Purposive Sampling. Penelitian ini bersifat eksperimental dengan tiga kali pengulangan, menggunakan metode One Group Pretest Posttest with Control. Variabel adalah dua jenis madu dan bakteri yang berbeda. Alat yang digunakan adalah cawan petri, kertas saring, pelobang kertas, lem, jarum ose, lampu spritus, tabung reaksi, lidi kapas steril, pinset, otoklaf, inkubator, dan Mistar. Bahan yang digunakan adalah Biakan murni Escherichia coli dan Staphylococcus aureus, $\mathrm{NaCl}$ 0,9\%, Alkohol 70\%, Agar darah, Medium Mueller Hinton, Medium DST, dan Madu. ${ }^{(4,10)}$

\section{Hasil dan Pembahasan}

Tabel 1.Hasil Diameter Daerah Bebas Pertumbuhan Escherichia coli

\begin{tabular}{|c|c|c|c|c|c|}
\hline \multirow[t]{2}{*}{ No } & \multirow{2}{*}{$\begin{array}{l}\text { Jenis } \\
\text { Madu }\end{array}$} & \multicolumn{3}{|c|}{ Pengulangan } & \multirow{2}{*}{$\begin{array}{c}\text { Rata- } \\
\text { rata } \\
(\mathrm{mm})\end{array}$} \\
\hline & & I & II & III & \\
\hline 1 & $A$ & - & - & - & - \\
\hline 2 & $B$ & - & - & - & - \\
\hline 3 & C & - & - & - & - \\
\hline 4 & $D$ & - & - & - & - \\
\hline 5 & $E$ & - & - & - & - \\
\hline 6 & $\mathrm{~F}$ & - & - & - & - \\
\hline
\end{tabular}

Dari tabel 1 didapatkan sebuah kesimpulan. Pengujian pertama didapatkan bahwa madu asli Sikabu $(A, C, E)$ dan madu Lubuk Minturun (B,D,F) tidak memiliki efek antibakteri terhadap Escherichia coli. 
Tabel 2. Hasil Diameter Daerah Bebas Pertumbuhan Staphylococcus aureus

\begin{tabular}{cccccc}
\hline \multirow{2}{*}{$\begin{array}{c}\text { N } \\
\text { O }\end{array}$} & $\begin{array}{c}\text { Jenis } \\
\text { Madu }\end{array}$ & \multicolumn{3}{c}{ Pengulangan } & \begin{tabular}{c} 
Rata- \\
\cline { 3 - 5 } rata (cm)
\end{tabular} \\
\hline 1 & $\mathrm{~A}$ & I & II & III & \\
2 & $\mathrm{~B}$ & 2,8 & 3 & 3 & 3,5 \\
3 & $\mathrm{C}$ & 3 & 2,8 & 3,3 & 3,03 \\
4 & $\mathrm{D}$ & 3 & 2,7 & 3 & 2,9 \\
5 & $\mathrm{E}$ & 3,2 & 2,5 & 3 & 2,9 \\
6 & $\mathrm{~F}$ & 2,5 & 3 & 2 & 2,5 \\
\hline
\end{tabular}

Dari tabel 2 didapatkan sebuah kesimpulan. Pengujian kedua didapatkan bahwa terdapat perbandingan efek antibakteri madu asli Sikabu $(A, C E)$ dengan madu Lubuk Minturun $(B, D, F)$ di mana madu asli Sikabu $(A, C, E)$ memiliki rata-rata efek antibakteri yang lebih baik terhadap Staphylococcus aureus, dibandingkan dengan rata-rata daya hambat yang dihasilkan oleh madu Lubuk Minturun (B,D,F). Hasil penelitian juga menunjukkan uji statistik dengan menggunakan uji one way ANOVA yang dilanjutkan dengan menggunakan metode RAL (Rancangan Acak Lengkap) Dua Faktor. Hasil pengolahan statistik yang didapatkan menunjukkan bahwa pengaruh efek antibakteri kedua madu terhadap Staphylococcus aureus tidak berbeda secara signifikant $(<0,05)$.

Madu Sikabu dan Lubuk Minturun merupakan dua madu yang berasal dari daerah yang berbeda di Sumatera Barat.Kedua madu ini memiliki letak geografi dan lingkungan yang berbeda. Berdasarkan penelitian yang dilakukan oleh peneliti, madu asli dari Sikabu bisa mendapatkan sumber saripati dari beberapa tumbuhan yang berasal dari lingkungan madu tersebut diambil, seperti padi, durian, karet, jengkol, rambutan, mangga, dan lain-lain.Sedangkan madu Lubuk Minturun mendapatkan saripati yang berbeda dibandingkan dengan madu Sikabu, di mana madu Lubuk Minturun mendapatkan saripati yang lebih dominan dari tumbuhan coklat. Informasi tersebut bisa menjadi salah satu faktor yang dapat membedakan perbedaan kemampuan efek antibakteri madu yang berasal dari daerah yang berbeda.

Berdasarkan hasil penelitian yang dilakukan oleh peneliti, Madu Sikabu dan Lubuk Minturun tidak mempunyai efek antibakteri terhadap Escherichia coli, sedangkan kedua madu ini memiliki perbandingan efek antibakteri terhadap Staphylococcus aureus. Hasil penelitian membuktikan bahwa madu Sikabu mempunyai efek antibakteri yang lebih baik terhadap Staphylococcus aureus jika dibandingkan dengan madu Lubuk Minturun.

Tabel 1 didapatkan bahwa kedua madu tidak memperlihatkan diameter daerah bebas kuman ketika diuji dengan Escherichia coli, tetapi kedua madu ini memiliki efek antibakteri yang berbeda terhadap Staphylococcus aureus. Diameter daerah bebas kuman yang terbesar terdapat pada madu $A$ (madu Sikabu), yaitu $3,5 \mathrm{~cm}$. Diameter daerah bebas kuman yang terkecil terdapat pada madu $F$ (madu Lubuk Minturun), yaitu $2,5 \mathrm{~cm}$.

Hasil ini juga didukung oleh uji statistik yang menunjukkan bahwa efek antibakteri kedua madu terhadap Staphylococcus aureus tidak signifikant. Hal ini bisa disebabkan oleh jenis bunga dan sifat lebah yang berasal dari kedua wilayah tersebut. Letak geografi kedua wilayah yang terletak pada lokasi yang tidak jauh dan sifat dari lebah untuk terbang dan mengambil saripati dari beberapa jenis bunga yang samadari kedua wilayah memberikan hasil statistik bahwa efek antibakteri kedua madu tersebut terhadap Staphylococcus aureus menunjukkan hasil yang tidak berbeda secara signifikant.

Penelitian yang telah dilakukan tentang efek antibakteri madu yang berasal dari wilayah berbeda kepada Escherichia coli, Staphylococcus aureus, dan Pseudomonas aureginosa. Ilmuwan telah menguji aktivitas antimikroba dari madu Chili yang dibuat oleh Apis mellifera (lebah madu) yang berasal daripohon Ulmo (Eucryphia cordifolia) dan madu Manuka yang berasal dari pohon Manuka (Leptospermum scoparium). Penelitian tersebut menghasilkan suatu perbedaan dari sifat kedua madu sebagai antibakteri, yakni menunjukkan bahwa madu Ulmo memiliki efek antibakteri yang unggul dibandingkan madu Manuka. Hasil penelitian berdasarkan aktivitas antibakteri berdasarkan pada zona kliring yang dihasilkan. Penelitian yang dilakukan dengan berbagai konsentrasi yang diberikan, Madu Ulmo selalu menghasilkan efek antibakteri yang lebih baik daripada madu Manuka kepada ketiga bakteri yang diberikan. Hal tersebut berkaitan dengan aktivitas kandungan, konsentrasi, tekanan osmotik, dan kadar gula tinggi yang dimiliki oleh madu tersebut sehingga mampu memberikan efek antibakteri kepada bakteri yang diuji. ${ }^{(6)}$

Apabila dihubungkan dengan dua madu yang diuji pada penelitian ini, yaitu madu yang berasal dari Sikabu dan Lubuk Minturun terhadap Escherichia coli dan Staphylococcus aureus. Penelitian yang dilakukan menunjukkan hasil yang berbeda di mana kedua madu tersebut tidak memiliki efek antibakteri terhadap Escherichia coli dan memiliki efek antibakteri terhadap Staphylococcus aureus. Hal ini mungkin disebabkan oleh sifat dari kedua kuman yang berbeda dan sifat dari kedua madu itu sendiri, di mana aktivitas kandungan, konsentrasi, tekanan osmotik, dan gula tinggi yang dimiliki oleh madu akan mempengaruhi aktivitas madu sebagai efek antibakteri terhadap bakteri seperti penelitian yang telah dilakukan terhadap madu Ulmo dan Manuka yang berasal dari negara Chili.

Dua kesimpulan dapat diambil dari penelitian ini bahwa tidak terdapat efek antibakteri kedua madu terhadap Escherichia coli dan terdapat perbandingan efek antibakteri kedua madu terhadap Staphylococcus aureus. Hal ini mungkin disebabkan oleh letak greogafis dari kedua madu tersebut dihasilkan dan perbedaan sifat yang dimiliki oleh bakteri Escherichia coli dan Staphylococcus aureus.

\section{Simpulan}

Berdasarkan penelitian yang telah dilakukan tentang perbandingan efek antibakteri madu asli Sikabu dengan madu Lubuk Minturun terhadap Escherichia coli dan Staphylococcus aureus secara in vitro dapat diambil kesimpulan bahwa madu asli Sikabu dan Lubuk Minturun tidak memiliki efek antibakteri terhadap Escherichia coli, dan kedua madu ini memperlihatkan diameter bebas kuman yang berbeda terhadap Staphylococcus aureus. Madu asli Sikabu memiliki efek antibakteri yang lebih baik dibandingkan dengan madu Lubuk Minturun terhadap Staphylococcus aureus, walaupun secara statistik tidak berbeda secara signifikan. 


\section{Daftar Pustaka}

1. Jawetz E, dkk. Mikrobiologi Kedokteran. Jakarta : EGC. 1996:236-238

2. Josodiwondo, Suharno. Kokus Negatif Gram. Dalam Mikrobiologi Kedokteran, FKUI. Jakarta : Binarupa Aksara. 1998:163-165

3. Nicolaas J Bason, Sias R Gobler, 2008. Antimicrobial Activity of Two South African Honeys Produced from Indigenous Licospernum Cordifolium and Erica Species on Selected Micro-organism. BMC Complementary and Alternative Medicine.From :www.biomedcentral.com

4. Notoatmodjo, Soekidjo. Metodologi Penelitian Kesehatan. Jakarta : PT Rineka Cipta. 2010:58-59

5. Oesman, Nizam, 2009. Kolitis Infeksi. Dalam (Sudoyo, A.W., Setiyohadi, B., Alwi, L., Simadibrata, M.K., Setiati, S., ed) IImu Penyakit Dalam, ed 5, Jakarta : Pusat Penerbitan Departemen IImu Penyakit Dalam Fakultas Kedokteran Universitas Indonesia, 563-564

6. Orla Sherlock, Anthony Dolan, Rahma Athman, Alice Power, Georgina Gethin, Seamus Cowman, et al, 2010. Comparison of The Antimicrobial Activity of Ulmo Honey from Chile and Manuka Honey Against Methicilin-Resistant Staphylococcus aureus, Escherichia coli, and Pseudomonas aureginosa. BMC Complementary and Alternative Medicine.From: www.biomedcentral.com
7. R, Aden. Manfaat dan Khasiat Madu. Yogyakarta: Hanggar Kreator. 2010:13-23

8. Rasyid, Ahmad. Abses paru. Dalam (Sudoyo, A.W., Setiyohadi, B., Alwi, L., Simadibrata, M.K., Setiati, S., ed) IImu Penyakit Dalam, ed 5, Jakarta : Pusat Penerbitan Departemen IImu Penyakit Dalam Fakultas Kedokteran Universitas Indonesia. 2009:2323

9. Saqa, Muhammad. Pengobatan dengan Madu.Jakarta : Pustaka Al-Kautsar. 2010:315

10. Handayani, Ria. Perbandingan Daya Hambat Madu Murni dengan Madu Kemasan terhadap Shigella dysentriae secara In Vitro.Skripsi. 2007:22-24

11. Warsa, Usman Chatib. Kokus Positif Gram. Dalam Mikrobiologi Kedokteran, FKUI. Jakarta : Binarupa Aksara. 1994:103-110

12. Yanping $P$. Chen, Jay D. Evans, Charles Murphy, Robin Gutell, Michael Zuker, Dawn Gundensen-Rindall, et al, 2009. Morphological, Molecular, and Phylogenetic Characterization of Nosema ceranae, a Microsporidian Parasite Isolated from the European Honey Bee, Apis mellifera : Journal Compilation by the International Society of Protistologists. 